\title{
Aura and Authenticity and the Presentation of UK Literary Figures through the Medium of the Home
}

\author{
Dr James Pardoe, University of Chester, UK
}

\begin{abstract}
By exploring case studies from the UK, this paper investigates how the notions of aura and authenticity at literary homes are utilised to create an impact on the understanding of the lives and works of associated writers. The boundaries of this paper have been dictated by its place within twenty-first century manifestations of the survival, conservation and reproduction of literary homes associated with four writers active in the early nineteenth century: Lord Byron, John Keats, Sir Walter Scott and Percy Shelley. Many of the works within the literary house genre highlight the significance of the link between writers and their audiences. However, whereas commentators concentrate on the links being direct, this paper shows that the association is based on narratives validated through those who were subsequently responsible for the houses in conjunction with the expectations of visitors. Consequently, the interpretation prevalent in the houses in the twenty-first century are the result of a long history based on the writers, but influenced by what was, and is, considered their significance by others over approximately two hundred years.
\end{abstract}

Keywords: Literary, Homes, Interpretation, Aura, Authenticity, Sensory, Markers

Aims

The boundaries of this paper have been dictated by its place within twenty-first century manifestations of the survival, conservation and reproduction of literary homes associated with four writers active in the early nineteenth century. It focuses on British writers of the Romantic age, and investigates the four houses which are associated with their names and which are open to the public today: Lord Byron (Newstead Abbey), John Keats (Keats House), Sir Walter Scott (Abbotsford House), all in the UK; and Keats and Percy Shelley (the Keats-Shelley Memorial House), located in Rome but managed by a UK organisation.

The principal aim of this paper is to show how writers' homes have been utilised to create a tangible representation of the associated writers' lives and works and how the notion of authenticity is used to validate this interpretation. It also aims to show how visitor expectations have shaped the current presentations at the houses. A central theme is how 
visitors' perception of an aura of the writers has influenced the way the houses have been interpreted.

\section{The Establishment of Four Literary Homes}

\section{Abbotsford House}

In 1811 Scott bought Newarthaugh, a modest five-room farmhouse, on the banks of the River Tweed near Melrose in the Scottish Borders some 41 miles south-east of Edinburgh. Scott renamed the farm 'Abbotsford House' (henceforth Abbotsford), reviving its historical links to the nearby Melrose Abbey. The estate originally comprised 110 acres, but by 1825 it had grown to ten times that size after Scott bought up neighbouring properties. The house also gradually increased in size with the first building phase from 1816 to 1818 including a tower, armoury, dining room and study. In 1818 Scott was raised to a baronetcy and, in keeping with his elevated position, three years later a further phase of work began: the old farmhouse was demolished and a second part of the new house was completed. The present day entrance hall, Scott's study, the library, and the sitting-room were all completed by 1825 . Externally the structure resembled a sixteenth-century Scottish fortified house. Historical references continued inside, which was filled with objects both of Scottish national history and of the history of Scott's family. (Figure 1) 


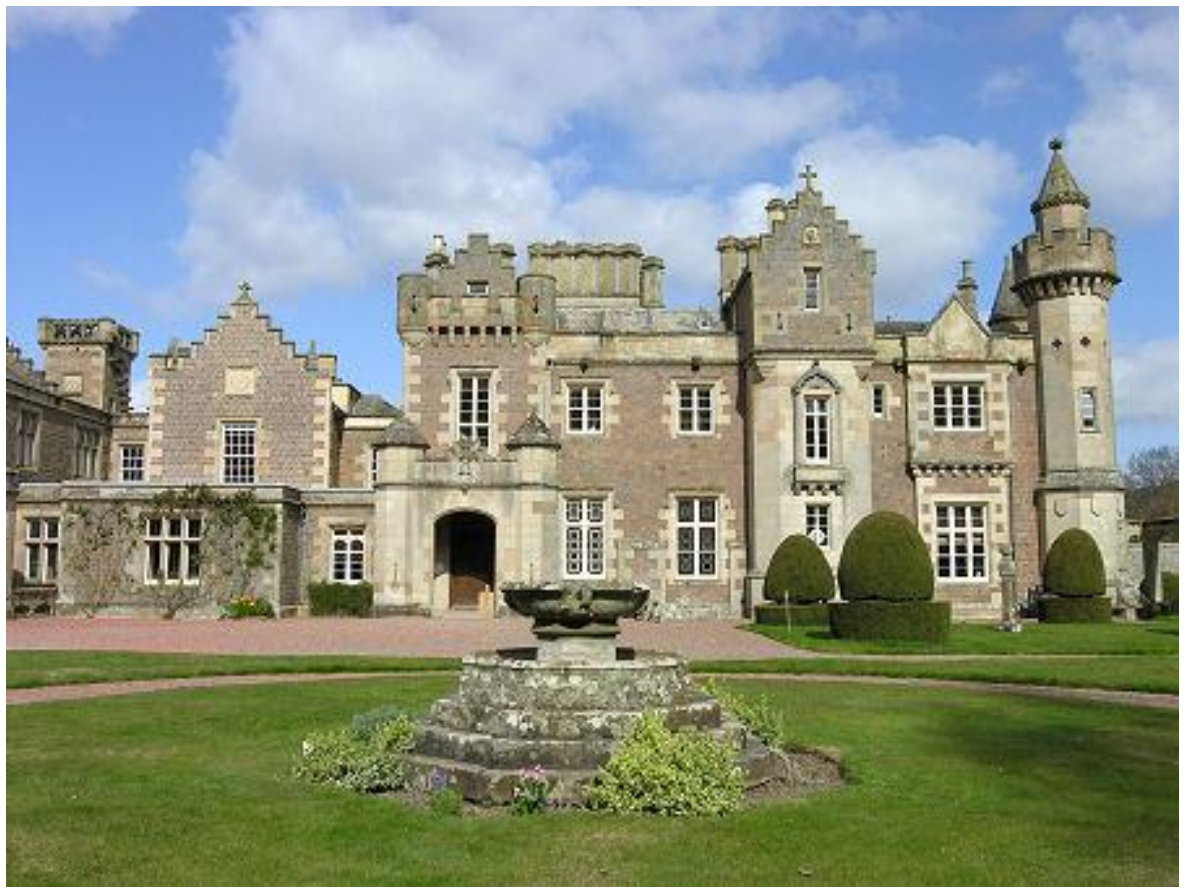

Figure 1 - South view of Abbotsford

Scott's obsession with Abbotsford and its place as the vehicle of much of his literary work made it a significant literary destination during his lifetime. It has remained open to the public to the present day. On his death in 1832 the house remained in the Scott family who promoted Abbotsford from the outset as the home as Scott had left it, including the furnishings and fittings. With the death of Dame Jean Maxwell-Scott in May 2004 the future of the house was in some doubt as her descendants showed little inclination to continue her work. However, in 2006 a Trust was formed to undertake the management of the property. Evidence, to date, suggests it will continue to be interpreted along the lines maintained by Scott's family for many years.

\section{Newstead Abbey}

An early focus for those with an interest in Byron was Newstead Abbey (henceforth Newstead) An early focus for those with an interest in Byron was Newstead Abbey 
(henceforth Newstead) located in a large estate 12 miles north of Nottingham in the English east Midlands. Newstead was founded as an Augustinian Priory in about 1160 by Henry II. The original buildings would have been in the Romanesque style, but very little remains from this time. The Priory followed a typical plan of a monastery with a large church abutted by a range of buildings around a square cloister on its south side. Throughout the lifetime of the religious community there would have been a number of building phases, some of which have survived to the twenty-first century, notably the west front of the church dating to circa 1270 and the cloister from the mid-fifteenth century.

Byron came into possession of his ancestral home in 1798 (aged ten), selling it nineteen years later to his Harrow school friend, Thomas Wildman. During this time Byron, who had lived there for no more than three years, made minimal physical impact on the building, although on its sale he did leave a number of personal objects in situ. Wildman invested large sums of money on a major renovation which reflected the influence of the emerging revival of Gothic architecture. Almost all evidence of post-medieval architecture was erased and the building was refaced in Gothic style masonry. In 1859, Wildman died without children, and Newstead was eventually sold in 1861 to William Frederick Webb. Webb continued to make additions to the house, again in the Gothic Revival style. Despite these architectural alterations and the dispersal of collections a number of accounts attest to the position of Newstead as the place to be visited because of its Byron connections. ${ }^{.}$Today Newstead is considered to be an important Byron house as it contains a significant Byron collection, and certain aspects of Byron's home as he knew it can still be accessed. (Figure 2) 


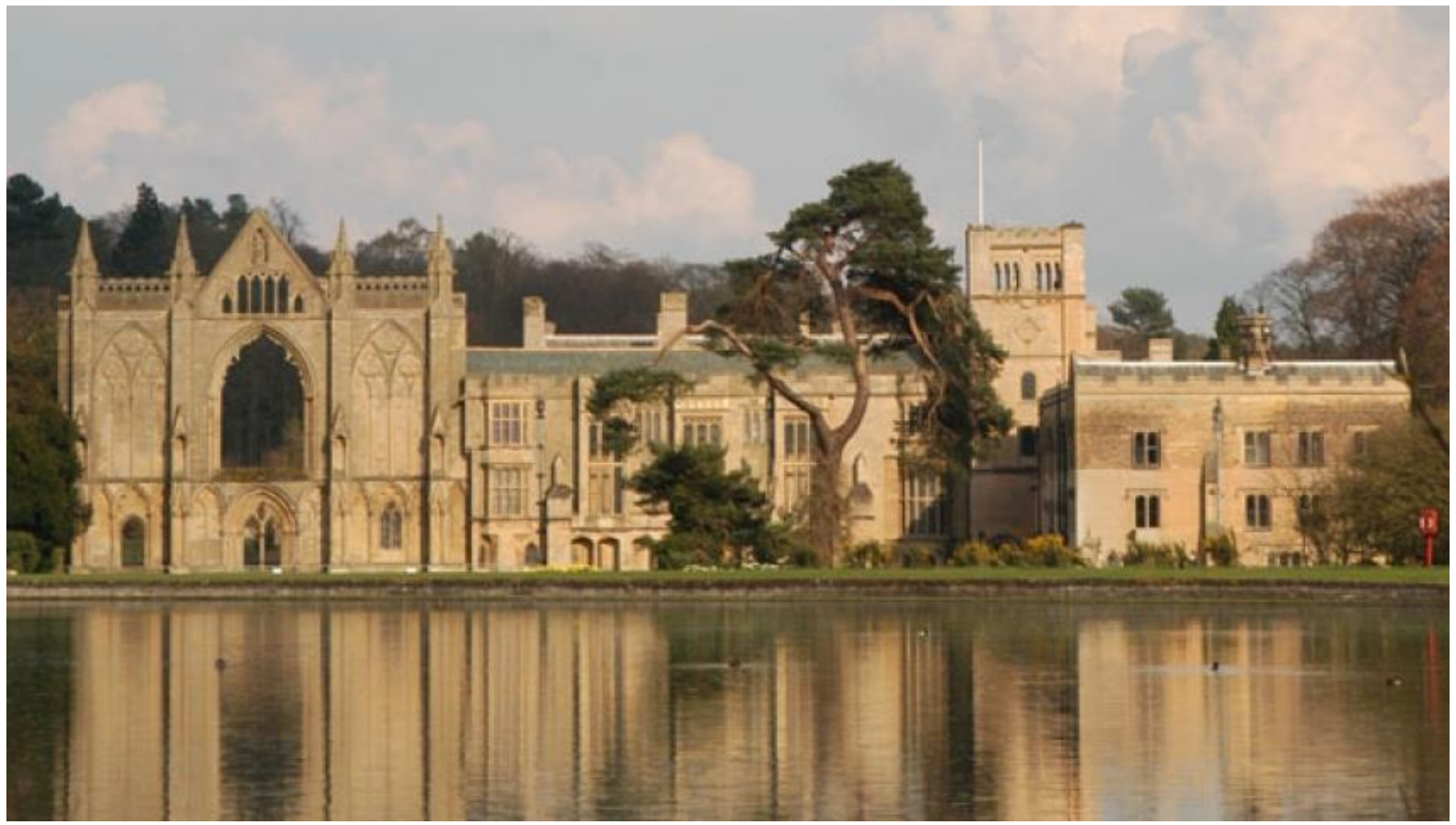

Figure 2 Newstead Abbey West Front

Newstead and Abbotsford have much in common; they were popular destinations during the lifetimes of their associated writers and significant collections were left in situ by those writers. From the time the writers left, these objects were not only incorporated into private family homes, but were set out in a form to replicate the use of these houses as they had been during the writers' ownership. They were also recognised without rival as the literary homes of Byron and Scott. With the writers Keats and Shelley, however, a number of differences emerge, not least that neither has an associated property with an unrivalled claim to be the destination for either writer.

\section{Keats House}

Unlike Byron and Scott, Keats never owned a home. He lived at Wentworth Place, Hampstead in London from 1818 to 1820 , where he wrote some of his most critically acclaimed poems, including Ode to a Nightingale. This was also the house where he met his fiancée, Fanny Brawne, the elder daughter of his next door neighbour. It was from this house 
that, suffering from tuberculosis, he left to spend the winter of 1820-21 in Italy, taking up residence in Rome, where it was hoped that he would find a cure in a milder climate. All of these events established strong connections between the writer and the Hampstead house. However, these links were not celebrated for another century, with the house largely remaining out of the public gaze and in private hands until it was threatened with demolition in the 1920s. It was eventually saved by public subscription and opened to the public as a museum in 1925 (renamed Keats House), since this time it has been managed by various local government organisations. Although it was considered as an important location for the production of Keats's best-known works, little physical evidence of his occupation remained.

Wentworth Place was built in the form of a modest suburban villa in 1814 by William Woods, a local builder, and completed in 1816 as two properties: it was the smaller of the two which was occupied by Charles Brown and where Keats came to live in 1818. The larger house was first occupied by Charles Wentworth Dilke who let it to Fanny Brawne's mother in 1819 . Keats stayed in the house for just seventeen months before travelling to Italy where he died. For much of the following century the house disappeared from the public gaze, remaining in private hands and even changing its name from that which Keats, or his circle, would have known. The house was converted into one property by Eliza Chester in 1838-39, and in April 1839 it was renamed Wentworth Place - having been recorded as being called Wentworth Cottage in March 1838. After Eliza Chester left in 1848, there were eleven more residents, the last one being George Manning Whiley who moved in during 1898. It was only in 1895, when the Royal Society of Arts erected a plaque on the outside of the house that the first public recognition was made of Keats's residence there. In terms of the contents of the house, nothing remained from Keats's occupation, and a collection had to be acquired that could form the focus of interpretation. In fact, a collection was already owned by the Borough of Hampstead, acquired in 1911, ten years before the house, and placed in the Public 
Library at Hampstead. This was the Dilke Collection of 'Keats Relics' which had been a private collection held in Chelsea between 1891 and 1911. (Figure 3)

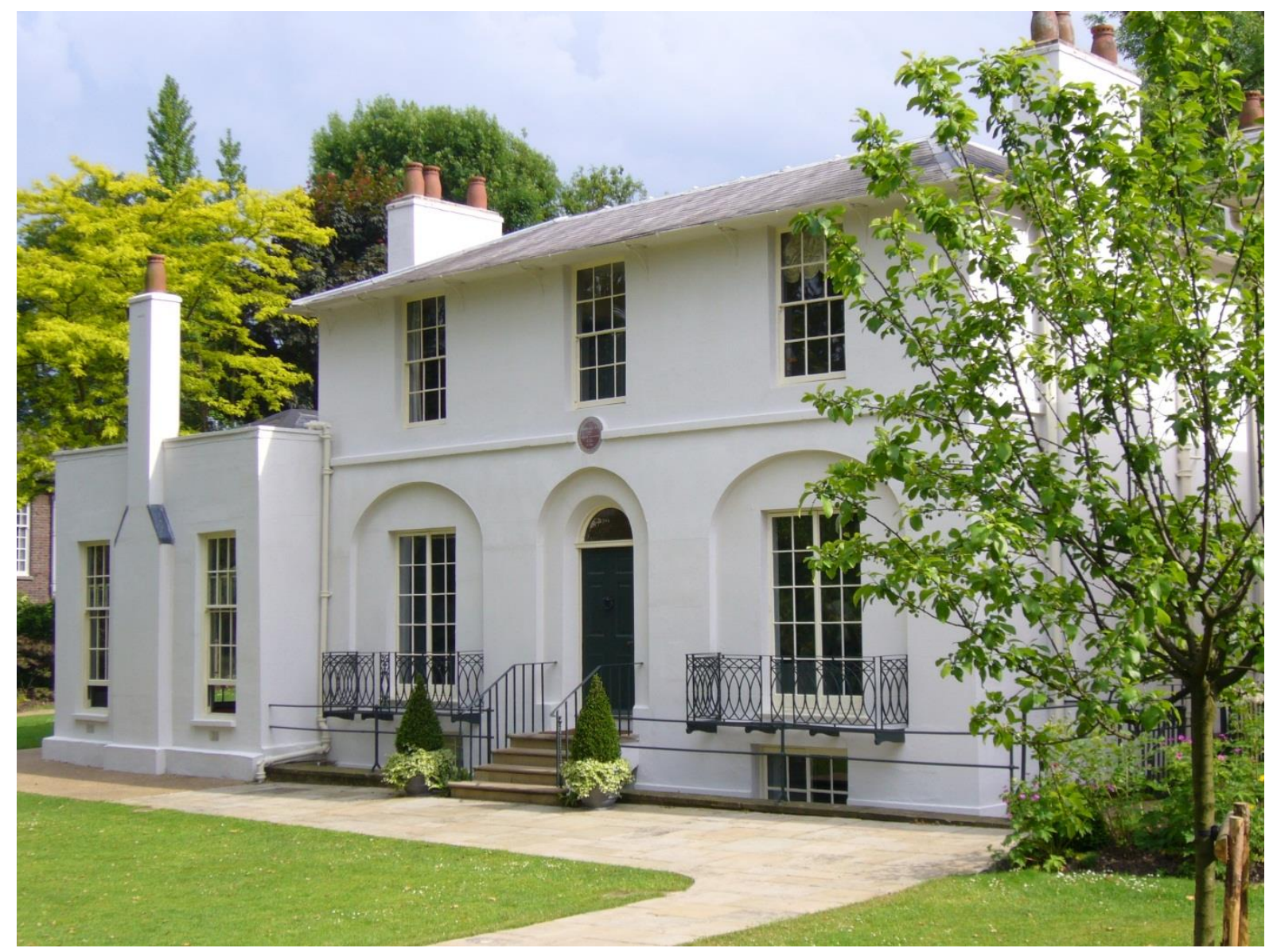

Figure 3 Keats House Front Elevation

\section{Keats-Shelley Memorial House}

For just over three months, from $15^{\text {th }}$ November 1820 to $22^{\text {nd }}$ February 1821 , a second floor apartment at Piazza di Spagna 26 in central Rome was home to Keats. Although this was where he died, he did not produce any of his works here, and no objects remained from this brief period of his life apart from a small number of letters written from this address to Fanny Brawne. There are records of a house on this site from the sixteenth century when the area became known as Piazza di Spagna after the rebuilding of the Spanish Embassy in 1567. The 
stone boat fountain known as the Barcaccia, just below the house in the Piazza is known to have existed in 1576, but was remodelled by the sculptor Pietro Bernini in 1627. This and the external redesign of Piazza di Spagna 26 in the 1720s were in place when Keats arrived in 1820 , and remain to the present day.

Internally the building was arranged over four floors each with a different set of apartments. After 1815 the area around Piazza di Spagna had become a centre for the English on the Grand Tour and it was here, at No. 26, that Dr James Clark found a modest apartment on the second floor for Keats and his friend, Joseph Severn in 1820. (Figure 4)

As with the situation at Keats House, the writer's occupation of this location was not celebrated until the twentieth century. The Keats-Shelley Memorial Association bought the house and officially opened it as a museum and library on $3^{\text {rd }}$ April 1909, with objects on display being drawn from a variety of donations. These objects had no direct associations with the house and the few pieces of furniture placed within the building to represent the house when it was occupied by Keats were reproductions. The motivation behind those responsible for the creation of the Keats-Shelley Memorial House (henceforth the KSMH) was both to provide a memorial to the Romantic writers in Italy, and also to establish a library, archive and study centre. Over the next one hundred years, the KSMH was established as the pre-eminent centre in Rome for visitors who sought connections with both Keats and Shelley. 


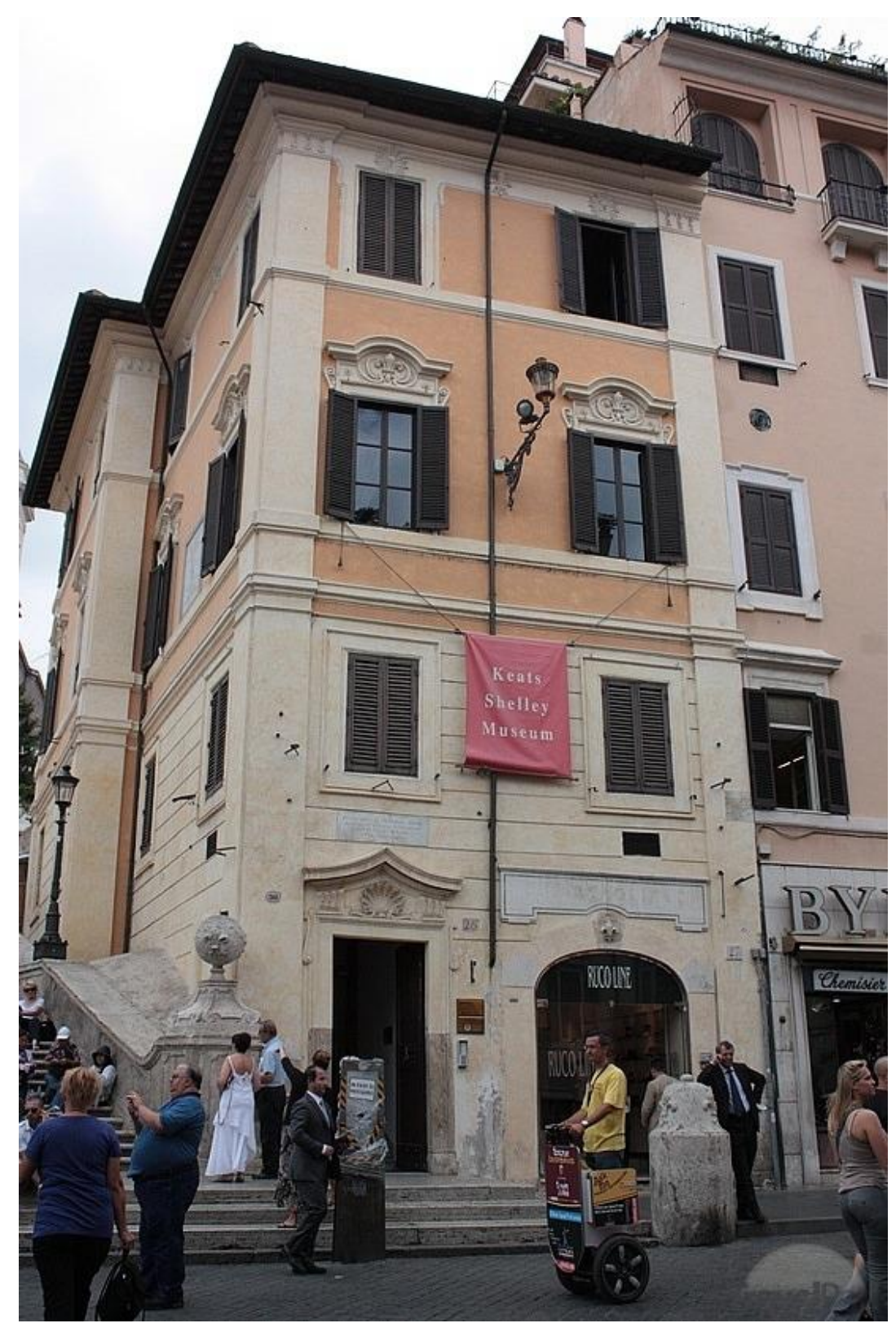

Figure 4 Keats-Shelley Memorial House

\section{The Impact of Aura and Authenticity}

So why are these homes considered to be appropriate mediators of the identities of the writers? And how have the notions of aura and authenticity impacted on these identities? 
The practices of literary homes have a profound impact on the way we interact with the lives and works of literary figures and what we select from those lives and works as having value. Values by definition are associated with ideals which are contemporary rather than of the past, and therefore discussions surrounding the definition of literary house practice concern its status as being about contemporary society rather than the past, and how particular elements of that past are chosen and passed on to future generations. But how do specific elements achieve the status of being valued and subsequently selected for 'saving' and presentation to future audiences? In many ways this status comes from the fact that a link to the past can be established for these elements, and they can be presented as being 'original', in other words of unimpeachable historic validity; in essence a validity derived from their authenticity.

The establishment of authenticity in the literary home context is a complex issue which raises an important question: If authenticity is to be based on the 'original' how is this measured?. The framework established by Ning Wang can be of use here. ${ }^{\text {ii }}$ As Wang identified, two kinds of authenticity exist: the authenticity of objects, whereby resources from the past can be described as being authentic or inauthentic depending whether they measure up to scientific standards, and existential authenticity, that is the authenticity of experience. Wang suggests that both terms can co-exist but that the latter has more power to explain visitor experiences not relying on the authenticity of objects. An investigation of the four literary houses used here identifies examples of value being applied through a focus on objects held in their collections which are deemed to have an unimpeachable historic validity. However, the limits to the extent of this validity have necessitated an emphasis on the notion of the value of 'sense of place'. This may be achieved through a range of experiences from just being in a spot where an event may have occurred to reconstructions which enable an 'aura' of a place 
to be experienced. Consequently, an analysis of the subjects outlined here also requires a definition of the concept of 'aura'.

A consideration of, the works of Cornelius Holtorf and Troy Lovata proves useful in this context. iii Holtorf and Lovata recognise the importance of reception, suggesting the aura of an object is created or fixed during its production, but changes according to where and when it is observed. In effect, 'aura' is not inherent in objects from the past but is activated by the reaction of an audience; Holtorf gives several examples of museum-goers who do not realise they are seeing replicas or copies and nonetheless experience the kind of aura generated by 'original' objects. All the houses chosen as case studies here are reproductions to a greater or lesser extent and the spirit of the writers is an important element in the manipulation of understanding who they are. An examination of the houses' interpretation shows 'aura' to vary unpredictably based on several factors, one of which is the audience's prior knowledge and expectations. For example, the US author Nathaniel Hawthorne complained in 1857 that a visit to Abbotsford House was, "[as] little more than going to a museum", iv and a twentyfirst century visitor to the Keats-Shelley Memorial House explained how he was awestruck by what he thought was Keats's last view. ${ }^{v}$ On the one hand, conscious that this was a reproduced Abbotsford, Hawthorne failed to find an 'aura' of Scott, whereas, on the other hand, the twenty-first century visitor, content that the bedroom replicated Keats's final hours, was able to experience his 'aura' therein.

Bruno Latour and Adam Lowe's conceptualization of the production and transmission of 'aura' where 'aura' migrates from originals to copies is also valuable. ${ }^{\text {vi }}$ They analyse the reaction of a visitor who is much more enthusiastic about the copy of Veronese's Nozze di Cana in Palladio's refectory on the island of San Giorgio, in Venice, than the original in the Louvre. In this case the visitor's knowledge of the context of where the painting was first housed in Venice was significant; this significance being enhanced by the fact that this was 
also the place for which the painting was commissioned. In Venice the reproduction was displayed in its historical setting: at the right height, the light in the room was relevant to the painting's subject, as was the juxtaposition of the architecture of the room and the architecture of the painting. To this visitor the spatial context gave the copy an 'aura' which the original no longer had; in effect, 'the aura of the original had migrated from Le Louvre to San Giorgio...' ${ }^{\text {vii }}$ Similarly, a consideration of the examples outlined here show that the aura of the writer is visitor-produced and dependent on the visitor's prior knowledge and expectations.

\section{The Medium of the Home}

The prevalent narrative at all the houses under discussion is based upon levels of authenticity in terms of how far each of the writers can be experienced at these sites. The unbroken narratives at Abbotsford and Newstead have enabled both owners and visitors to discover authentic 'Scott' and 'Byron' houses while the disjointed histories of Keats House and the KSMH have resulted in the need for 'reproduced' narratives and artefacts. Nevertheless at all four sites, sensory markers ${ }^{\text {viii }}$ are deployed to authenticate links to the associated writers.

The presentation of the writers at each of the houses was, and is, influenced by visitor expectations, which in turn were fashioned by these visitors experiencing the spirit of the writers and a sense of place, that is aura, and to discussions surrounding how current curators perceive aura to be intrinsic to the sites. Aura is used, at all four of these houses, to enhance authenticity and thereby establish validity for the homes.

Analysis into these four houses shows that the link between the writers and the audiences is less important than the link between audiences and those responsible for the houses since their adoption as literary destinations. The legacy of each of the writers is filtered through those who are, and have been, responsible for the houses: in shorthand, the 'owners'. The 
result of this filtration process has been found to be dependent upon the notion of 'aura', which is itself dependent on which narrative is fashionable at any given time according to what the owners wish to legitimise and what visitor expectations are. These different layers of narrative and expectation - and the interaction between the two - in turn have their own legacy. The histories of the houses are therefore critical in understanding how each of the writers are interpreted and viewed at each of these sites.

Although the four houses chosen for this paper have much in common, a number of differences can be identified, not least resulting from their respective histories over the past two centuries. The ties attaching Abbotsford and Newstead to their respective writers were strong, while at Keats House and the KSMH they were limited. Scott was linked to the area around Abbotsford from his early childhood (in 1773 when he was aged two) and through family ties. These associations were cemented through his legal and administrative role (from 1799) which required him to travel the region extensively. It was also during this period that he began to produce some of his important literary works. Scott strengthened his connections to the area by setting up a permanent home from 1804 . When he bought, named and built up his house and estate from 1811 Abbotsford gradually became a focus for historical references linking Scott, his family and Scottish national history. It also became a vehicle for his literary works and Scott designed the layout of the house to act as a visitor destination. All these elements could be sourced through Scott's Journal, his letters, Reliquiae Trotcosienses, and through the thoughts of his contemporaries. ${ }^{\text {ix }}$

Newstead undoubtedly played a role in Byron's life, both whilst he owned the estate and after its sale in 1817. It stood as a symbol for his long line of aristocratic ancestors, and it was the subject of his letters and verse from 1803 until 1823, particularly On leaving Newstead Abbey (1803), to Elegy on Newstead Abbey, The Adieu and To an Oak at Newstead (all 1807) and Newstead Abbey (1811). These works have been interpreted both as examples of Byron's 
attachment to his home and as valuable sources that describe the house during his residence. ${ }^{\mathrm{x}}$ However, the most extensive descriptions of Newstead occur in Cantos 13 and 16 of Don Juan (1823), although it has been argued that these verses are evidence of regret at the sale of Newstead and have also been used as sources to describe Byron's house.

In contrast, although there is no denying Keats wrote some of his finest works while living at Keats House, there are no sources to suggest he had any particular attachment to the house, and it is not the subject of any of his verse. In Rome Keats did not produce any literary works and, as far as is known, Shelley was not familiar with the building with which he is now linked. Instead, all attachments to these sites were proposed by posthumous narratives advocated by others. We are dealing, therefore, with four houses whose links to their writers differed significantly and where issues of authenticity, aura and interpretation have to be addressed in different contexts.

The unbroken narratives at Abbotsford and Newstead have enabled both owners and visitors to discover authentic 'Scott' and 'Byron' houses while the disjointed histories of Keats House and the KSMH have resulted in the need for 'reproduced' narratives and artefacts. In the case of the latter two sites, sensory markers are deployed to authenticate links to Keats and Shelley. By contrast, we find sensory markers at Abbotsford and Newstead which have been in place since the writers' time. For example, the public rooms at Abbotsford have largely remained intact with objects such as Scott's iconic desk and chair remaining in place in his Study and Scott's collection of artefacts relating to Scottish history in the Entrance Hall. At Newstead, of the Byron Relics that can be seen in the house, some such as his bed, are in the places where Byron used them, albeit in an adapted form, and others such as the paintings of his dogs now found in the house but in different locations from where they were reputedly hung by Byron. However, the sensory markers encountered at Keats House, now include a new external decorative scheme and the aligning of a new path to follow the route to the 
entrance of the house which would have been used by Keats. The aim is to create a link with the environment where Keats composed Ode to a Nightingale. Inside, original life and death masks, an inkstand and writing desk trigger narratives of Keats's life at the house, his literary production and the onset of his terminal illness. At the KSMH the markers all relate to the atmosphere of the locality surrounding the Spanish Steps, with specific reference being made to what Keats may have heard from outside as he lay dying, for example the Barcaccia fountain. The death narrative is demonstrated through Severn's death-bed portrait of Keats above the 1820s 'boat-bed' (purchased in 2003) representing Keats's own bed, and a print of the Protestant Cemetery in Rome. The death narrative continues through the display of an alabaster urn containing a fragment of Shelley's jawbone taken from his cremation. Physical links to the two writers are provided through locks of their hair.

At Abbotsford, the necessity to present the house as providing a sense of place can be seen in the fact that despite an enduring emphasis by the owners and some visitors on the ability to recognise Scott's house physically frozen in time at the point of his death, what resulted from the period between 1832 and 2004 quite openly challenges this assertion. The physical evidence of Scott's house was replaced by a co-produced representation, in that Abbotsford developed from a symbolic form of Scott's self-portrayal to an image fashioned by the interaction of the subsequent owners and visitors.

At Newstead, the survival, conservation and reproduction of the 'Byron elements' over the approximate 200 year history of the post-Byron house has generated a range of competing responses surrounding the make-up of the house as a Byron literary site. The majority of responses to Newstead since Byron sold the house in 1817 have questioned how much of Byron could be experienced at the house. A key, and highly contested, question raised therefore has been whether Newstead was, and is, Byron's House or a Byronic House that is, a nineteenth century gentleman's country residence incorporating a Byron memorial. Despite 
the possibility of evidencing a substantial Byron house, this could only be achieved by metaphorically peeling back the layers of the Byronic House, and it is the latter which is the reality in the twenty-first century.

With Keats House and the KSMH, to be able to analyse the ways in which they became recognised, adopted and adapted as representations of Keats and Shelley, it is important to examine the construction of the status of the two writers. Once the houses were 'created' as literary destinations they then established histories of their own, divorced from Keats's and Shelley's own experiences at these sites. It is the culmination of these histories which are presented today and at the heart of those interpretations is the narrative of the 'aura' of the writers which can be experienced.

The post-writer histories at each of the houses were influenced by visitor expectations, which in turn were fashioned by these visitors experiencing the spirit of the writers and a sense of place. This is linked to discussions surrounding how current curators perceive aura to be intrinsic to the sites to legitimise the significance and value of the houses. The curators Jacqui Wright at Abbotsford, Haidee Jackson at Newstead, Stephanie Healey at Keats House and Catherine Payling at the $\mathrm{KSMH}^{\mathrm{xi}}$ - all bring this spirit of the associated writers into their interpretation of the houses. Hence at Abbotsford, Wright constantly refers to how much of the house was original and authentic to Scott, enabling an evocation of what he experienced at this site. At Newstead, Jackson makes the point that by analysing Byron's handwriting on his original works - which are on display at the house - an insight into Byron's thoughts at the time can be gained. With Keats House and the KSMH, for Healey and Payling an experience of authenticity is achieved through a sense of place which is evoked through a reproduction of events in the life of Keats, for example at Keats House the replication of the Ode to a Nightingale garden border, and at the KSMH the daisies painted on the ceiling of Keats's bedroom and the replica bed. 
Owner motivation for presenting the notion of aura has also been influenced by economic factors. These were linked to prevailing visitor expectations. At Keats House from 1925, Newstead from 1931, and Abbotsford since 2004, examples can be found of the owners having to adapt their narratives and interpretation to make their houses more popular to a wider selection of visitors. However, even for the owners of Abbotsford and Newstead, prior to 2004 and 1931 respectively, and at the KSMH from 1909, when income was not a prerequisite for attracting audiences, their motivations were: at Abbotsford a sense of duty to make available Scott's significant legacy to the public; at Newstead as reverence for Byron and to enhance the family's status as part of a neo-feudal political statement; and at the $\mathrm{KSMH}$ to act as guardians of the building, the writers' memory and their connections to Italy. Therefore, even though the reasons for appealing to visitors changed over time, visitor expectation was influential in how the writers were presented.

\section{Conclusion}

In conclusion each of the four houses is different in terms of its meaning to the writer, its intrinsic merit beyond the writer, its subsequent ownership and presentation history. Nevertheless, key similarities between them can be determined: in all four houses their validity is closely linked to the ability of their owners to associate these homes with an authenticity, whether through verifiable scientific data and/or an aura which may be experienced. In turn, visitors seek 'aura', whether or not there are physical remains associated with the writer. However, this 'aura' is dependent on whether the houses in the twenty-first century can 'speak' to their audiences.

Each house has its own specific story to tell. A study of the four cases outlined here allows for an analysis of the production and consumption of the perceptions of four literary figures 
across a range of contrasting examples, and over a long period of history. In doing so, the impact of interactions between a variety of owners and different types of visitor and the significance of the writers at particular historical moments may be assessed.

In setting out to identify the importance of these houses in the understanding of their four associated writers this paper has provided the first analysis of literary homes through a consideration of the impact of a history of interactions between owners and visitors. In demonstrating new levels of complexity associated with the original contexts, historical narratives, and present-day perceptions, this study will advance our understanding beyond that so far covered in the literature. This will in turn provide further insight into the many debates that still surround literary destinations, and perhaps facilitate further evaluations of the homes of famous literary figures as part of our appreciation of their literature and their lives.

\section{Notes}

\footnotetext{
i Irving, W. 1850. Abbotsford and Newstead Abbey. London: Henry G. Bohn, Howitt, W. 1857. Homes and Haunts of the Most Eminent British Poets - Vol.II, $2^{\text {nd }}$ edn. London: Richard Bentley, Chew, S. 1924. Byron in England - His Fame and After-Fame. First published New York: Russell \& Russell, 1965 - re-issue, Marchand, L. 1957. Byron a Biography. New York: Alfred A. Knopf, , Beckett, J. 2001. Byron and Newstead-The Aristocrat and the Abbey. London: Associated University Press, Coope, R. and Smith, P. 2014. Newstead Abbey: A Nottinghamshire Country House: Its Owners and Architectural History 1540-1931. Nottingham: Thoroton Society of Nottinghamshire.

ii Wang, N.1999. Rethinking Authenticity in Tourism Experience. In Annals of Tourism Research, Vol.26, No.2: 349-370.

iii Holtorf, C. 2005. From Stonehenge to Las Vegas: Archaeology as Popular Culture. Walnut Creek, CA: Alta Mira, Lovata, T. 2007. Inauthentic Archaeologies - Public Uses and Abuses of the Past. Walnut Creek, CA: Left Coast Press.

iv Stewart, R (ed). 1941. The English Notebooks by Nathaniel Hawthorne (Based upon the original manuscripts in the Pierpont Morgan Library.) New York: Russell and Russell, p.540.

$v$ Author's informal conversation with visitor during preliminary tour to public areas of Keats House, London July 2005 .

${ }^{v i}$ Latour, B. and Lowe, A. 2011. The migration of the aura or how to explore the original through its facsimilies. In T Bartscherer and R Coover (eds). Switching Codes. Thinking Through Technology in the Humanities and the Arts. Chicago: University of Chicago Press: 275-97.

vii Ibid. p. 277

viii Sensory markers are the physical objects and spaces which enable remembrance and memorialisation to occur.
} 


\footnotetext{
${ }^{i x}$ Anderson, W. (ed). 1998. The Journal of Sir Walter Scott. Edinburgh: Canongate, Carruthers, G. and Lumsden, A. (eds). 2004. Walter Scott - Reliquiae Trotcosienses. Edinburgh: Edinburgh University Press, Irving.

${ }^{\times}$Coope, R. and Smith, P., Watson, N. (ed). 2009. Literary Tourism and Nineteenth-Century Culture. Basingstoke: Palgrave MacMillan, Marsh, K. (ed). 1993. Writers and their Houses - A Guide to the Writers' Houses of England, Scotland, Wales and Ireland - Essays by Modern Writers. London: Hamish Hamilton, Hendrix, H. (ed). 2008. Writers' Houses and the Making of Memory. London: Routledge.

xi Stephanie Healey, Visitor Services Manager, Keats House, interview by James Pardoe, Keats House, $19^{\text {th }}$ August 2005, Haidee Jackson, Senior Keeper Newstead Abbey, interview by James Pardoe, Newstead Abbey, $17^{\text {th }}$ June 2006, Catherine Payling, Curator, Keats-Shelley Memorial House, interview by James Pardoe, KSMH, $12^{\text {th }}$ July 2005, Jacqui Wright, Executive Manager, Abbotsford Trust, interview by James Pardoe, Abbotsford House, $15^{\text {th }}$ August 2007.
}

\section{WORKS CITED}

Anderson, W (ed). 1998. The Journal of Sir Walter Scott. Edinburgh: Canongate.

Beckett, J. 2001. Byron and Newstead - The Aristocrat and the Abbey. London: Associated University Press.

Carruthers, G. and Lumsden, A. (eds). 2004. Walter Scott-Reliquiae Trotcosienses.

Edinburgh: Edinburgh University Press.

Chew, S. 1924. Byron in England - His Fame and After-Fame. First published New York: Russell \& Russell, 1965 - re-issue.

Coope, R. and Smith, P. 2014. Newstead Abbey: A Nottinghamshire Country House: Its Owners and Architectural History 1540-1931. Nottingham: Thoroton Society of Nottinghamshire.

Stephanie Healey, Visitor Services Manager, Keats House, interview by James Pardoe, Keats House, $19^{\text {th }}$ August 2005.

Hendrix, H. (ed). 2008. Writers' Houses and the Making of Memory. London: Routledge. Holtorf, C. 2005. From Stonehenge to Las Vegas: Archaeology as Popular Culture. Walnut Creek, CA: Alta Mira.

Howitt, W. 1857. Homes and Haunts of the Most Eminent British Poets - Vol.II, $2^{\text {nd }}$ edn. London: Richard Bentley.

Irving, W. 1850. Abbotsford and Newstead Abbey. London: Henry G. Bohn.

Haidee Jackson, Senior Keeper Newstead Abbey, interview by James Pardoe, Newstead Abbey, $17^{\text {th }}$ June 2006.

Latour, B. and Lowe, A. 2011. The migration of the aura or how to explore the original through its facsimilies. In T Bartscherer and R Coover (eds). Switching Codes. Thinking Through Technology in the Humanities and the Arts. Chicago: University of Chicago Press: 275-97.

Lovata, T. 2007. Inauthentic Archaeologies - Public Uses and Abuses of the Past. Walnut Creek, CA: Left Coast Press.

Marchand, L. 1957. Byron a Biography. New York: Alfred A. Knopf.

Marsh, K. (ed). 1993. Writers and their Houses - A Guide to the Writers' Houses of England, Scotland, Wales and Ireland - Essays by Modern Writers. London: Hamish Hamilton.

Catherine Payling, Curator, Keats-Shelley Memorial House, interview by James Pardoe, KSMH, $12^{\text {th }}$ July 2005.

Stewart, R (ed). 1941. The English Notebooks by Nathaniel Hawthorne (Based upon the original manuscripts in the Pierpont Morgan Library.) New York: Russell and Russell. Wang, N.1999. Rethinking Authenticity in Tourism Experience. In Annals of Tourism Research, Vol.26, No.2: 349-370. 
Watson, N. (ed). 2009. Literary Tourism and Nineteenth-Century Culture. Basingstoke: Palgrave MacMillan.

Jacqui Wright, Executive Manager, Abbotsford Trust, interview by James Pardoe, Abbotsford House, $15^{\text {th }}$ August 2007.

\section{ABOUT THE AUTHOR}

Dr James Pardoe: I am a Senior Lecturer responsible for Heritage Management at the University of Chester, UK on both History and Archaeology programmes. I have also lectured at Bournemouth University, the University of Edinburgh, the University of Warwick, the Ironbridge Institute (all UK), Eotvos Lorand University of Budapest and Aarhus University, Denmark. I am currently Visiting Professor at University of Bydgoszcz, Poland. I have experience in museums dating back to 1986 including working for the National Trust, English Heritage, Shropshire Regimental Museums, Chester City Museums, Nottingham City Museums and Galleries and the Abbotsford Museum Trust.

My research interests focus on heritage management, literary tourism, museology, landscape history, country houses, access for disabled people to the historic environment, and modern history (Eastern Europe).

I have published and worked as a consultant for a number of organisations in these areas both in the UK and further afield, including curating museum exhibitions and work on EU funded projects. I have also acted on the committee for the UK based Association for Heritage Interpretation and I am presently a judge for the AHI Discover Heritage awards. 